\title{
The concept of cooking skills: A review with contributions to the scientific debate
}

\section{O conceito de habilidades culinárias: uma}

\section{revisão com contribuições ao}

\section{debate científico}

\author{
Manuela Mika JOMORI ${ }^{1}$ (D) 0000-0003-2294-6692 \\ Francisco de Assis Guedes de VASCONCELOS ${ }^{1}$ (D) 0000-0002-6162-8067 \\ Greyce Luci BERNARDO1 (D) 0000-0003-0411-012X \\ Paula Lazzarin UGGIONI ${ }^{1}$ (D) 0000-0003-2696-0539 \\ Rossana Pacheco da Costa PROENÇA ${ }^{1}$ (D) 0000-0001-6149-8752
}

\section{A B S T R A C T}

This paper aimed to conduct a literature review about the concept of cooking skills to contribute to the scientific debate about the subject. A systematic search was performed in the Scopus, PubMed/MedLine and Web of Science databases as well as the periodicals of the Federal Agency for Support and Evaluation of Graduate Education in Brazil Coordenação de Aperfeiçoamento de Pessoal de Nivel Superior website, using the following Portuguese and English keywords: cooking skills, cooking and food/meal preparation. We also consulted references cited by these papers, electronic dictionaries (in Portuguese, English and French), technical documents found on public and private institutional websites, as well as books. Basic, etymological/vernacular and systematic definitions for cooking were identified, including historical global and national contexts. To conceptualize cooking skills,

\footnotetext{
$\overline{1}$ Universidade Federal de Santa Catarina, Programa de Pós-Graduação em Nutrição, Núcleo de Pesquisas de Nutrição em Produção de Refeições, Campus Reitor João David Ferreira Lima. s/n., Trindade, 88040-900, Florianópolis, SC, Brasil. Correspondência para/Correspondence to: RPC PROENÇA. E-mail: <rossana.costa@ufsc.br>.

Support: Coordenação de Aperfeiçoamento de Pessoal de Nível Superior, Doctoral Sandwich Program Abroad (PDSE) and Universidade Federal de Alagoas, Doctoral Scholarship.

Article based on the doctoral thesis of MM JOMORI, entitled "Adaptação transcultural e validação de um instrumento de identificação das habilidades culinárias e alimentação saudável em estudantes ingressantes de uma universidade brasileira". Universidade Federal de Santa Catarina; 2017.
}

Como citar este artigo/How to cite this article

Jomori MM, Vasconcelos FAG, Bernardo GL, Uggioni PL, Proença RPC. The concept of cooking skills: A review with contributions to the scientific debate. Rev Nutr. 2018;31(1):119-135. https://doi.org/10.1590/1678-98652018000100010 
categories related to food and individuals were established, purposing a conceptual model. The category related to food referred to the use of unprocessed/minimal processed foods (which require procedures prior to their preparation), and/or processed/ultra-processed foods (which need a little or no preparation, such as re-heating). The category related to individuals involved dimensions such as confidence, attitudes, behavior, and individual knowledge used to prepare foods. The historical definitions of cooking allowed us to clarify the concept of cooking skills. Considering the global context of valuing and recovering cooking for the promotion of healthy eating, this review can contribute to the scientific discussion about the concept of cooking skills. The purposed conceptual model enables parameters to be established for further investigations, allowing cooking interventions to be directed toward promoting healthy eating.

Keywords: Cooking. Convenience foods. Dietetics. Food handling. Meals.

\section{R E S U M O}

O objetivo do artigo foi realizar uma revisão de literatura sobre o conceito de habilidades culinárias, a fim de contribuir para o debate científico sobre o tema. Foi realizada busca sistemática de artigos nas bases de dados Scopus, PubMed/MedLine, Web of Science e portal de periódicos da Coordenação de Aperfeiçoamento de Pessoal do Ensino Superior, utilizando os seguintes descritores em português e inglês: habilidades culinárias, culinária, preparo dos alimentos/das refeições. Consultaram-se ainda referências citadas por esses artigos, dicionários eletrônicos (nos idiomas português, inglês e francês), documentos técnicos capturados em sites institucionais públicos ou privados, bem como livros. Identificaram-se definições para culinária denominadas como básicas, etimológicas/vernáculas e sistemáticas, incluindo um resgate histórico da culinária no contexto mundial e no Brasil. Para conceituar habilidades culinárias, foram estabelecidas categorias relacionadas aos alimentos e aos indivíduos, propondo-se um modelo conceitual. A categoria relacionada aos alimentos refere-se ao uso de alimentos in natura/minimamente processados (que requerem procedimentos prévios ao seu preparo), e/ou processados/ultraprocessados (que requerem pouco ou nenhum preparo, como reaquecimento). A categoria relacionada aos indivíduos envolveu dimensões como confiança, atitude, comportamento e conhecimentos individuais empregados para preparar os alimentos. As definições históricas de culinária permitiram elucidar o conceito de habilidades culinárias. Considerando o contexto mundial de valorização e resgate da culinária na promoção da alimentação saudável, essa revisão pode contribuir para o debate científico em torno do conceito de habilidades culinárias. O modelo conceitual proposto possibilita estabelecer parâmetros para avaliação em futuras investigações, permitindo direcionar intervenções culinárias para promoção da alimentação saudável.

Palavras-chave: Culinária. Dietética. Manipulação de alimentos. Fast foods. Refeições.

\section{NTRODUCTIO N}

In the last two decades, the theme of 'cooking skills' has been the focus of investigations and interventions in different countries [1-8]. However, the concept of cooking skills still does not seem to be sufficiently discussed, starting with definitions of the term cooking. Under one of the approaches, the definition of cooking would be restricted to the application of heat to raw foods. Nevertheless, the term can present more complex meanings, when perspectives from different fields of knowledge are considered [1,4,6-10].

Cooking skills have been referred to as the ability to perform tasks related to the preparation of food, which requires preliminary procedures to its cooking, such as washing, peeling, and chopping [1,4,8-10]. Researchers mention that cooking confidence and knowledge are fundamental requirements to the development of individual cooking skills $[1,2,6,7,11-13]$.

The emergence of scientific interest in this theme seems to be associated with a contemporary global context of encouraging adoption of healthy and sustainable eating practises. Studies demonstrate that better levels of cooking skills, such as attitudes and confidence in preparing food or the frequency in the preparation of the meals at home, may promote healthy eating habits, especially in regard to the increase in the consumption of fruit and vegetables $[1-4,7,8]$. 
The scientific literature indicates that a decline in the cooking skills of an individual is a factor that negatively influences these practises. One of the aspects that may justify this decline is related to the decrease in the transmission of cooking knowledge between generations and in schools. The lack of confidence in executing cooking tasks is also considered a barrier to performing these skills $[1-4,6-8,11,14,15]$.

Nonetheless, it must be pointed out that cooking skills may not have been reduced, but only be due to the different ways of making food at home. Execution of cooking tasks using unprocessed foods require procedures preliminary to their preparation, while cooking tasks using processed or ultra-processed foods can be executed with minimum preparation. Although some processed or ultra-processed foods may only require heating for final consumption, studies show that this activity may require some cooking skills $[1,6,7,9,15]$. The predominant and frequent use in this latter category of foods has been related to the possible reduction of cooking skills, and it is considered as one of the factors that may hinder healthy dietary practises $[1,2,4,6-8,10,13,15,16]$.

Therefore, public policies in various countries have recommended the use of strategies to rescue and foster the development of cooking skills, as part of elements that promote healthy and sustainable eating [17-23]. In this field of knowledge in Brazil, documents such as the Marco de Referência em Educação Nutricional (Food and Nutrition Education Reference Framework) and the last version of the Guia Alimentar para a População Brasileira (GAPB, Food Guide to the Brazilian Population) may be referenced $[21,23]$. A reflection carried out by Brazilian authors also discusses the rescue and recovery of cooking as an object of study to broaden the dialogue of cooking with Nutrition Science [24].

The scenario is promising for the discussion of this subject, since there is neither a consensus on the definition of cooking skills nor a consistent theoretical debate on it. Thus, a significant gap in the studies that evaluates cooking skills and their relationship with healthy eating deserve to be highlighted [1,4,5,8-10,12].

This article aims to conduct a literature review on the concept of cooking skills to contribute to the scientific debate.

\section{METHODS}

A systematic search was conducted for articles in the databases of Scopus, PubMed/ Medline, and Web of Science from January to March of 2015, updated in July 2016, with no restrictions on publication dates of articles or other search filters. This search was carried out for the intersection of the following Englishlanguage descriptors: 'cooking skills', 'culinary', 'food preparation', 'meal preparation'. Studies cited by the publications captured were also consulted by the snowball technique.

Another search using the same Portuguese-language keywords ('habilidades culinárias', 'culinária', 'preparo dos alimentos', 'preparo das refeições') was performed in the portal of journals, the Coordenação de Aperfeiçoamento de Pessoal de Nível Superior (CAPES, Coordination of Improvement of Higher Education Personnel), in books and websites of public and private institutions, and Google Scholar. Moreover, Portuguese, English, and French dictionaries (digital or not) were consulted. The focus on cooking was examined in specific historical contexts, in chronological order, with the purpose of identifying events of international and Brazilian contexts.

The definitions of cooking in Portuguese (culinária, cozinha, or cozinhar), in English (culinary, cookery or cooking), and in French (cuisine) were classified in accordance with approaches to cooking in the fields of Nutrition and Human Sciences. The first classification referred to the words 'cooking', 'kitchen', or 'to cook' that have been mentioned in articles and dictionaries of different languages, so they were called basic 
definitions. The second classification originated from sources that examined the origin of the word, more than its concept, in the etymological or vernacular sense. The last classification, whose definitions were called systematic, was based on the approaches of classical works of different disciplines and fields of knowledge.

Another analysis was conducted to identify the similarities between the definitions of terminology given to foods/ingredients, and existing culinary techniques in the national and international bibliography included in the study. This comparison was made based on the degree of processing and preparation of food.

Common elements of the selected studies that could compose the categories related to foods and individuals were used in the final construction of a conceptual model for cooking skills.

Based on the above, the text is structured considering the focus of cooking in different historical moments in the world and in Brazil, as well as the construction of the concept of cooking skills in contemporaneity.

\section{The focus of cooking at different historical moments in the world and in Brazil}

The focus of cooking has shifted with specific historical moments in some countries, contributing to its definition; the differences can be observed in classical and contemporary authors of Brazil, and authors from other countries (Chart 1).

Since ancient times, Hippocrates' diet principles have predominated the field of cooking; the main goal was to make the food digestible and foster good health. In France, the apology for flavour and gluttony has gained ground in the 13th century with the appearance of gourmands (greedy). Therefore, a contradiction in the basic principles of culinary dietetic was found. These dietetic principles did not aim to please the palate, fact that used to cause punitive manifestations. Thus, the focus on dietetic issue was being replaced by gastronomical aspects, until an emphasis on high gastronomy and culinary art was found in the mid-1600s. The cookbooks were removed

Chart 1. Focus of cooking at different historical moments, from antiquity until today, in the world and Brazil.

\begin{tabular}{|c|c|}
\hline Antiquity & Hippocrate' diet principles. Aim: to make the food digestible [25]. \\
\hline 13th century & Transition from dietary to gastronomical principles. Valuing flavor and gluttony - France [25]. \\
\hline 17th century & Valuing high gastronomy and culinary art - France [25]. \\
\hline 1926-1930 & $\begin{array}{l}\text { Inventory of food practises such as authentic, national and traditional cooking legacy, as well as black, } \\
\text { indigenous, and Portuguese miscegenation - Brazil }{ }^{\text {a }}[26-31] \text {. }\end{array}$ \\
\hline 1930-1940 & Diffusion of culinary, dietary kitchen, and dietary technique concepts by nutrologist - Brazil $[32,33,34,41]$. \\
\hline 1963 & Consolidation of the dietary technique in Nutrition courses - Brazil ${ }^{\mathbf{b}}$ [43]. \\
\hline 1967-1978 & Discussion on transformation of raw (food) into cooked (cultural) - France/ United Kingdom [44]. \\
\hline $1970-2000$ & New alimentary/dietary models in the field of Food and Nutrition - Brazil $[32,33,45]$. \\
\hline $1990-2000$ & $\begin{array}{l}\text { Removal of cooking classes from formal school curricula - United Kingdom/Canada/New Zealand/Brazil } \\
{[1,6,9,10,14,15,42,46] \text {. }}\end{array}$ \\
\hline $1993-2014$ & $\begin{array}{l}\text { Diffusion of cooking in TV shows, recipe books and the internet, as well as visibility of chefs United Kingdom/ } \\
\text { USA/Brazil }[1,15,47-54] \text {. }\end{array}$ \\
\hline 1995-2016 & $\begin{array}{l}\text { Bringing back cooking as an element of fostering healthy eating - United Kingdom/USA/Brazil } \\
{[1,3,4,5,7,9,10,12,24,55-58] \text {. }}\end{array}$ \\
\hline
\end{tabular}

Note: "First edition of "The Masters and the Slaves: A Study in the Development of Brazilian Civilization", published in 1933; first edition of "The Mansions and the Shanties: The Making of Modern Brazil", published in 1936; and "Sugar", published in 1939; 'First edition entitled "Dietary technique: Science and art in the kitchen" ("Técnica dietética: ciência arte na cozinha"), which was revised, expanded and published after the fourth edition as "Dietary technique: selecting and preparing food" ("Técnica dietética: seleção e preparo dos alimentos") [43]. "First edition of "The Raw and the Cooked", published in Brazil in 1964. 
from Medicine, Hygiene, and Diet sections, and considered a part of Art and Literature in that period. This fact was related to the emergence of Gastronomy, referred to as 'the new science of flavour' [25].

In Brazil, the beginning of the process of dissemination of the concept of cooking seems to be associated with the emergence of Nutrition Science in the country, a phenomenon that occurred in the second half of the 19th century [32]. The literature investigated suggests that the first thesis, on the relationship between eating habits and diseases of the Brazilian population, emerged in the country as of 1837 , in the two existing Medicine Colleges (Bahia and Rio de Janeiro) [32,33].

In the first three decades of the 20th century, with the institution of the science of Nutrition and other disciplinary fields, following the example of Sociology and Anthropology, the diffusion of the concept of cooking becomes more evident. Therefore, the book "A Arte Culinária na Bahia" ("The Art of Cooking in Bahia"), published in 1928, in Salvador, by Manuel Raimundo Querino (1851-1923), is one of the first national works to refer to the concept of cooking. In addition, the work praises the role of the African element in the constitution of the Bahian cuisine and its importance in the conformation of the Brazilian art of cooking [33].

Moreover, the Pernambuco state-born sociologist Gilberto Freyre (1900-1987) has been considered as one of the precursors to the use of the concept of cooking as a sociocultural identification component in the construction of the Brazilian nationality. In his 1926 "Manifesto Regionalista" ("Regionalist Manifesto") Gilberto Freyre called attention to the threats of deprivation of regional cooking characteristics, and he proposed some strategies to value the aesthetics and tradition in Northeastern cooking for the first time in the country $[26,27]$.

Other works by this author, published between 1930 and 1940, such as "The masters and the slaves: a study in the development of brazilian civilization" (1933), "The mansions and the shanties: The making of modern Brazil (1936), "Northeast" ("Nordeste: aspectos da influência da cana sobre a vida e a paisagem do nordeste do Brasil) (1937), and "Sugar" (1939), gather precious records about the process of formation of habits and eating patterns of Brazilian society. According to these works, such habits were products of food syncretism of Brazilian indigenous cooking (culinary), as well as of black African and white Portuguese, highlighting the ethnocultural focus on Brazilian regional cooking identity (authentic Brazilian cuisine). Thus, the word cooking, highlighted by Freyre in his works, was used as an element for defining food culture [26-31].

Subsequently, during the 1930s and 1940s, the first generations of Brazilian nutriologist, led by Josué de Castro (1908-1973), became the main broadcasters of the concepts of cooking, art of cooking, dietary kitchen, and dietary technique. As from the late 1930s, these nutrologist created the first courses for training dietitians in Brazil, in which the art of cooking and dietary kitchen (later dietary and cooking technique) constituted a disciplinary field, mandatory in the curricula. Several books and articles by these doctors, published between 1930 and 1950, were vehicles of dissemination of concepts of cooking and dietary techniques, both for professionals in the field of Food and Nutrition, and for the Brazilian population in general [34-41].

In the decades of 1950 and 1960, although cooking and dietary technique remained as compulsory subjects in the curricula of undergraduate courses in Nutrition in Brazil [42], it was found that throughout this period, there was a relative loss of its relevance in Nutrition Studies in the country [32,34]. An analysis of 209 articles, published in the Arquivos Brasileiros de Nutrição between 1944 and 1968, identified priority themes related to experimental nutrition and food technology. Cooking and dietary technique were in last place among the themes identified 
in these articles. It is worth to note that, at the end of this period, the emergence of the food industry was seen as a promising fact in combating hunger and formulating public policies on nutrition. Thus, the discussion of rationalisation of food dominated the themes, giving little space to cooking studies [34].

However, it must also be highlighted that cooking was featured in textbooks as an important object of study for Nutrition courses in the country from the 1960s onwards. From this decade, the 1963 publication Técnica dietética. ciência e arte na cozinha (Technical dietetic: science and art in the kitchen), by one of the first Brazilian dietitians, Lieselotte Hoeschl Ornellas, deserves to be highlighted. It must be pointed out that this work maintained this title until 1975. Then, it was changed to Técnica dietética, seleção e preparo dos alimentos (Dietary Technique, Selection and Preparation of Food), 4th edition, and this title was preserved until the eighth edition [43].

In the international context, in the field of Anthropology, in the 1960s, one of the major contributions to the debate about cooking was the work of the structuralist anthropologist Claude Lévi-Strauss: "The Raw and the Cooked", published in 1964, in France. This work discusses the transformation of raw food (nature) into cooked (culture) [44].

This anthropological approach was not articulated in Nutrition Science at the time; nevertheless, it was paramount to this discussion on the definition of cooking. Between the end of the 1970s and the mid-1990s, Nutrition Science examined epidemiological and interventional investigations centred on the concern with the biological functions of nutrients and their consequences for health, within the world nutritional transition framework. The context that permeates this picture might be associated with the scientific and technological development of the food industry and the nutritional epidemiological transition in this period $[34,45]$.
At the end of the 1990s, the withdrawal or the absence of cooking classes from the curricula of basic education [46], especially in the United Kingdom, also caused concern related to changes in cooking knowledge among young people $[1,6,9,10,14,15]$. It was against this background that the term 'cooking' seems to have been replaced by the term 'processing', which in this period, had a more scientific character for education in schools, which may have been influenced by the expansion of the food industry [14].

From 1990 until today, movements that sought to rescue cooking, including 'Slow Food', whose name stands in opposition to the emergence of fast foods in this period, have been found both on a global and a Brazilian level [26]. Other phenomena are also verified in the world: the trend of valuing cooking skills in the media by the dissemination of cooking shows on television featuring chefs and celebrities, books and magazines about cooking, and the display of these contents on the internet $[1,15,47-53]$. However, the dissemination of knowledge or information related to cooking appears not to have reached daily life, since this knowledge is more about an exquisite or professional way of making food. This differentiates domestic cooking from high gastronomy or the national and ethnic cuisines [6,47-54].

Cooking as an object of study of Nutrition courses in Brazil seemed to allow for an interaction with objects of Gastronomy courses, created in 1994 [26]. Although this dialogue has not been highlighted, in this period, cooking seems to be valued more in the context of Gastronomy. Gastronomy emerges as the new science of food, having become the focus of great chefs, but not of domestic cooking. This was also found in various other countries [47-54]. Moreover, from the 2000s on, researchers in the United States of America have defined cooking nutrition as a way of combining the knowledge of Nutrition Science with Gastronomy, highlighting the role of nutritionists, in the same way as the chef's does, in cooking interventions $[3,13]$. 
Following this decade, there are publications mentioning cooking as a possible aspect related to fostering healthy eating in some countries $[1,3,5-7,9,10,12,24,55-58]$. One of these studies considers this relationship as a contemporary phenomenon on a global scale, defining it as 'culinary cultures to diet' [6]. In Brazil, cookingrelated issues are currently referred to in few public policies on healthy eating $[21,23]$, and not extensively investigated in scientific literature $[24,55,59,60]$.

Considering the approaches to cooking throughout history, especially in Brazil, the different types of definitions found for cooking are illustrated in Chart 2.

The basic definitions were often limited to heating raw food. Nonetheless, the systematic definitions were more complex, differing according to the approaches of the fields of knowledge presented in this study.

\section{Construction of the concept of cooking skills in contemporaneity}

Based on the investigation of the definition of cooking, the concept of cooking skills found in some countries in the contemporary scenario of eating should be contextualized. The growing availability of convenience food, observed in several countries, seems to be influencing the possible decline of cooking skills, since they do not require previous preparation and/or preparation before consumption $[1,4,6,9,15]$. However, researches consider that using convenience foods involves some type of preparation, such as the use of technology (e.g., the microwave), characterizing a change in the pattern of preparing and consuming foods, but not necessarily a decline in cooking skills. This process has been designated as a 'culinary transition', referring to the experience of important changes in the pattern and type of skills necessary to prepare and consume the foods of various cultures over time. Thus, according to these authors, this transition would not imply the exclusion of a practise to the detriment of the other. However, it would be referred to by the use of food defined as basic (raw or fresh), combined with convenience food $[1,4,6,9,10,15]$.

In recent years, some studies, conducted with different approaches and audiences, found in their results that the meaning of home cooking differs among cultures [6,58]. For example, a comparative qualitative study carried out in France and Britain evaluated groups of 27 lay people and 19 experts on the theme of home cooking. For the French, home cooking might refer to using raw ingredients, considered more traditional. For the British, the preference seems to be for practicality and speed of convenience food, which may characterize the perception of a lack of a culinary identity [6]. Another study carried out with 27 adult residents in Ireland found that the perception of home cooking seems to range from cooking in a more traditional way to incorporation of ultra-processed foods, the latter symbolizing a version considered more modern [58].

Focus groups composed of adults of different ethnicities and gender, in Baltimore, United States of America, suggested that the meaning valued and preferred among the participants to define what is cooking at home was the question of scratch-cooking any food. However, many of them reported that they used ultra-processed food in their daily life, i.e., those that do not have to be prepared 'from scratch'. The meaning of cooking associated with the heating of food seemed unimportant to this public, since home cooking would include the preparation of any food, not necessarily subjecting it to heat [7].

In Brazil, the last version of the Guia Alimentar para a População Brasileira, prioritizes the recommendation for the use of unprocessed food, the use of minimally processed foods, the reduction of use of processed foods, and the 
Chart 2. Definitions of cooking, and kitchen or cooking terms found in dictionaries and bibliographies in the areas of Food, Nutrition and Human Sciences.

\begin{tabular}{lll}
\hline Sources & Cooking (to cook) & Culinary or cooking (cookery) \\
\hline & Basic Definitions ${ }^{*}$ & \\
\hline
\end{tabular}

\begin{tabular}{ll}
\hline MacQuarie Dictionary (2008) & 'To prepare (food) by the action of heating' \\
Aurélio Online Dictionary (2014) & $\begin{array}{l}\text { 'Conversion of raw material for the food cooked with } \\
\text { heating'. }\end{array}$ \\
MacMillan Dictionary online & $\begin{array}{l}\text { 'Art and science of food preparation for the table, generally } \\
\text { by heating until its flavour, consistency, appearance and } \\
\text { (2014) }\end{array}$
\end{tabular}

Oxford Dictionary online (2014) ${ }^{\mathbf{d}} \quad$ 'The practice or skill of preparing food by combining, mixing, and heating ingredients'.

Cuisine (historical): 'The kitchen defines territories, it becomes the art of producing food, in a technical sense, which is the very way human beings make good food'. 'Thus, it enables knowledge transmission'.

Dictionnaire des cultures

alimentaires (2012) [61]

Diez-Garcia (1995) [55] Cod

\section{Etymological or Vernacular Definitions*}

Cooking: It originates from the Latin word culinarius, derived from the Latin word culina (kitchen), related to the art of cooking. In a strict sense, it originates from a place to prepare food (kitchen). It is considered as a 'set of practises involving the handling of foods for alimentary purposes', consisting of the application of any technique to modify them from how they are obtained, such as a mixture and from a variety of foods.

Mintz (1996) [54]

Cuisine: In French language ${ }^{* *}$ means not only kitchen (kitchen as a physical, domestic space in the English language), but also cooking, which is originated in the Latin verb coquere (to cook), which also originated cocina (Spanish), cucina (Italian), küche (German), and kitchen (English). It may also designate the so-called high gastronomy.

\begin{tabular}{cl}
\hline \multicolumn{1}{c}{ Systematic Definitions $^{*}$} \\
\hline Lévi-Strauss [1964] (2010) $^{\mathbf{e}}$ [44] & $\begin{array}{l}\text { Cooking: Range of culturally accepted procedures used to transform the nature (raw) in culture } \\
\text { (cooked), i.e., how raw food become cooked through a process of cultural transformation. }\end{array}$
\end{tabular}

Brillat-Savarin (1995) [62]

Flandrin (1998) [25]

Cooking: 'Is the most ancient of the arts', above all, 'the one that provided us the most important service to civil life'.

Cuisine: Related to the emergence of valuing flavour and gluttony over food, which historically, in Europe, was influenced by dietary and therapeutic functions, legitimising itself in the French context of the end of the 17th century and early 18th century; the taste or 'good taste' in cooking practise. Culinary is featured in dictionaries of that time from terms such as cooking and spices with a dietary, gastronomic focus.

Fischler (2001) [63]

Anthropological function of culinary: The culinary framework occurs in three peculiarities to explain its anthropological function: 1) the omnivorous paradox ${ }^{* * *}, 2$ ) the incorporation principle (which considers edible), and 3 ) its borders and the nature of taste (the physiological function of taste and its meanings and cognitive ideals).

Barham (2002) [48]

Symons (2002) [64]

Cooking: Transforms indigestible food into edible food, increasing its options (for example, by means of cooking).

Cooking: It is more than the application of heat to food, verified in the definitions of dictionaries; it is also making them ready for use (such as the preparation of a salad, for example). It is based on approaches ranging from issues of taste (hedonism versus belief/religion) and nutrition (improving digestibility and food security); the modern approaches (involving cooking as a symbol); and materialistic ones (female domestic task supported by the male public work, considering the beginning of production chain influenced by domination and economic policy).

Poulain \& Proença (2004) [65]
'The expression manger la cuisine, even among the French may generate different interpretations, such as cuisine (or eating), in terms of: cooking (familiar, refined, etc.), products (natural, organic, etc.), culture and identity (traditional, regional, etc.), time or economic constraints (quick, cheap, etc.), and in nutritional terms (balanced, fat-free food, etc.)', as highlighted in Poulain (1998) [66] 
Chart 2.Definitions of cooking, and kitchen or cooking terms found in dictionaries and bibliographies in the areas of Food, Nutrition and Human Sciences.

1 of 2

\begin{tabular}{|c|c|}
\hline Sources & Culinary or cooking (cookery) \\
\hline \multicolumn{2}{|r|}{ Systematic Definitions* } \\
\hline Ornellas (1963) [43] & $\begin{array}{l}\text { Art of cooking: 'Aims to modify food, making it tastier and easier to digest'. } \\
\text { Cooking: A method that improves the nutritional, sensory and digestive food properties, part } \\
\text { of the food preparation stage (mixing and/or cooking and finishing) until its distribution for } \\
\text { consumption. }\end{array}$ \\
\hline
\end{tabular}

Note: "Basic definitions: Found in dictionaries; Etymological or vernacular definitions: Related to the origin of the word or term; Systematic

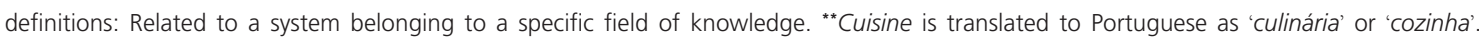

${ }^{* * *}$ Refers to the omnivorous being's choice of food, in his ability to eat anything, which leads, on the one hand, to food neophobia (prudence, resistance to novelty, aversion to the unknown) and on the other hand, to food neophilia (tendency to exploitation, need for change, novelty, and variety);

${ }^{a}$ Culinary/Cooking. Dictionary of English Language. Sydney: Publish Group Australia; 2008. [cited 2014 Jun 5]. Available from: <https://www. macquariedictionary.com.au>/ [10]; ${ }^{\mathbf{b}}$ Cooking / Kitchen. Dictionary of the Portuguese Language; 2008. [cited 2014 Jun 5]. Available from: <http://www.dicionariodoaurelio.com/>; 'CCulinary/Cooking. Dictionary of English Language. Britain: Macmillan Publishers Limited; 2009. [cited 2014 Jun 5]. Available from: <http://www.macmillandictionary.com>/; ${ }^{\mathrm{d} C u l i n a r y / C o o k i n g . ~ D i c t i o n a r y ~ o f ~ E n g l i s h ~ L a n g u a g e . ~ O x f o r d: ~ O x f o r d ~}$ University Press; 2013 [cited 2014 Jun 5]. Available from: <http://www.oxforddictionaries.com>l; ${ }^{\mathbf{e}}$ A primeira publicação da obra foi em 1964 na França.

elimination of consumption of ultra-processed foods. This recommendation reflects the stimulus to rescue the culinary act, since the use of processed and unprocessed foods might contribute to the decline in cooking skills. According to this logic, for the first time in Brazil, the mention of cooking skills as an element of fostering healthy eating is found $[16,23]$. In addition, there are frequent attempts to bring back traditional and regional cooking $[23,24]$.

It is considered that the possible divergences identified in the concept of cooking skills, such as the use of unprocessed and minimally processed foods as opposed to processed and ultra-processed ones, are not to be regarded as dichotomies, because they are still unclear. Taking this into account, an analysis of the terms is made to formulate a conceptual unit of cooking skills that embraces these differences.

Understanding the definition of the term 'skills', such as confidence in performing tasks, a definition of 'cooking skills' to be adopted would be the performance of a task that can be considered as both domestic or traditional, and artificial or technological' [9]. The domestic or traditional task involves the use of basic ingredients that require preliminary procedures to preparation (cooking from scratch) to become appropriate for consumption. On the other hand, the artificial or technological task refers to the use of foods already acquired with the support of preparation technologies, such as convenience foods, which might only require the use of the microwave oven $[1,15]$.

The domestic/traditional task is often featured in studies on cooking skills. However, basic foods/ingredients are not always described; they are only sometimes referred to as 'raw', or 'fresh or raw'. 'Cooking from scratch' is an expression frequently cited but little explored by studies, as if it were automatically understood. Generally, it opposes the use of ready-to-eat foods, because cooking from scratch requires the application of procedures before preparation, such as washing, peeling, and cutting food. The fact that this categorization is not described in depth seems to indicate the existence of a gap regarding food or cooking techniques called 'basic' in the definition of cooking skills $[1,4,6,8-12]$.

The artificial or technological task $[1,15]$ might be compared to the definitions adopted in Brazil, related to use of processed 
and ultra-processed foods, requiring minimal processing for their consumption $[16,23]$. Furthermore, another classification of foods found in the examined literature was based on five generations of food products. The first generation consists of basic ingredients/foods (raw, fresh or raw); these are subject to pre-preparation [67]. In comparison with the classification adopted by Guia Alimentar para a População Brasileira, this first generation is similar to unprocessed foods and some minimally processed foods $[16,23]$.

Second-generation products consist of food that undergoes appertization (preserved food). Third-generation foods are the (cooked or not) frozen ones. The fourth generation refers to (usually raw) convenience vegetables. Finally, fifth-generation foods involve preparations processed through packaging under controlled atmospheres (raw or cooked foods) [67]. Consequently, compared with the classification of Guia Alimentar para a População Brasileira, second-generation foods could be considered as processed, and the third to the fifth-generation foods could be considered as minimally processed $[16,23]$. With this in mind, the technological task would incorporate the use of third to fifthgeneration foods, which are processed with the use of technologies of different levels. As a result, they are characterized as convenience or ready-to-eat foods $[1,15,16,23,67]$.

To define cooking techniques deemed as basic, authors resume the preliminary procedures for preparation, or 'cooking from scratch', as a parameter to evaluate cooking skills $[1,4,6,8,9]$. Some few studies listed specific cooking techniques, all involving the application of heat (such as boiling, frying in immersion, stir-fry, using the microwave oven, etc.). In addition, they mentioned in passing, the 'knife skills', although they did not describe the cooking techniques involved [11,13].

As seen above, the steps of pre-preparation and preparation of foods involving the stages of the cooking processes have been mentioned since the first textbook on cooking and dietary techniques in Brazil [42]. These definitions contributed to the delimitation of basic cooking tasks that form the basis of the definition of cooking skills in this study, as shown in Chart 3.

According to this logic, the cooking skills necessary for cooking, from pre-preparation to the preparation, considering unprocessed and/or minimally processed foods, or only preparation or the re-heating related to processed and/ or ultra-processed foods deserve highlighting. The food pre-preparation stage, as defined by Ornellas since 1963, corresponds to what the international literature is defining as 'cooking from scratch' within the concept of cooking skills $[1,15,43]$.

Consequently, those forms in which cooking skills operate might directly interfere in the act of cooking, since preparation of meals does not originate from a single category of food or cooking technique in all occasions, but may blend with cooking practises, especially when urban cultures are considered $[1,4,6,8,9]$.

Moreover, it must be pointed out that exercising cooking skills, considering specifications of use of cooking techniques and foods, might provide a healthier diet $[1,4,6-9,15,16,23,58]$. A recent literature review rated cooking techniques and use of foods considered basic, based on evidence on which of these elements are related to focusing on the prevention of chronic noncommunicable diseases. From this, the authors delimited foods (fresh vegetables) and cooking techniques (e.g., avoiding fried foods and high-temperature techniques) that consisted of possible protective factors, formulating a model of cooking skills to prevent these diseases. However, although this model cites the use of unprocessed vegetables as healthy, the degree of processing refers only to using high temperatures in preparation of meat [8].

Moreover, the discussion on cooking skills goes beyond using food or techniques in the kitchen, for it depends on the analysis of individual issues, such as confidence in cooking and the individual's cooking knowledge [1-6]. 
Chart 3. Food and cooking techniques used to formulate the concept of cooking skills per different classifications.

\begin{tabular}{|c|c|c|c|c|}
\hline \multicolumn{3}{|c|}{ Classifications of food } & \multicolumn{2}{|c|}{ Classifications of cooking techniques $[1,4,6-11,13,15,43]$} \\
\hline $\begin{array}{l}\text { International } \\
\text { literature } \\
{[1,4,6-10,15]}\end{array}$ & $\begin{array}{l}\text { *Brazilian } \\
\text { recommendation }\end{array}$ & Generations [67] & Pre-preparation** & Preparation $^{* *}$ \\
\hline $\begin{array}{l}\text { Food/basic } \\
\text { ingredients }\end{array}$ & $\begin{array}{l}\text { UN or MP Food. } \\
\mathrm{CI} \text { may be included. }\end{array}$ & $\begin{array}{l}\text { First-generation } \\
\text { foodstuffs. } \\
\text { Raw vegetables (fourth } \\
\text { generation) and } \\
\text { meat foodstuffs (fifth } \\
\text { generation) may be MP. }\end{array}$ & $\begin{array}{l}\text { Mandatory procedures of } \\
\text { cleaning, subdivision and } \\
\text { union. } \\
\text { Cooking from the beginning } \\
\text { (cooking from scratch). } \\
\text { Optional use of } \mathrm{Cl} \text {. } \\
\text { Knife skills. }\end{array}$ & $\begin{array}{l}\text { Optional procedures (after } \\
\text { implementation of pre-preparation } \\
\text { techniques) of cooking in water, } \\
\text { without water, and mixed cooking } \\
\text { technique. } \\
\text { Preparation of raw salads consist of } \\
\text { pre-preparation itself. } \\
\text { Optional use of } \mathrm{Cl} \text {. }\end{array}$ \\
\hline $\begin{array}{l}\text { Convenience } \\
\text { foods/ } \\
\text { ready for } \\
\text { consumption }\end{array}$ & $\begin{array}{l}\text { P or UP food } \\
\text { Some MP foods } \\
\text { (such as milk and } \\
\text { oats, for example). }\end{array}$ & $\begin{array}{l}\text { Second to fifth- } \\
\text { generation foodstuffs. }\end{array}$ & $\begin{array}{l}\text { Procedures of union: } \\
\text { hydrating and mixing (for } \\
\text { some UP food, e.g., powder } \\
\text { products such as powdered } \\
\text { milk and chocolate milk). }\end{array}$ & $\begin{array}{l}\text { Optional procedures (with no need } \\
\text { for pre-preparation) of cooking in } \\
\text { water, without water, and mixed } \\
\text { cooking technique. } \\
\text { Heating (using a microwave oven). } \\
\text { Use of } \mathrm{Cl} \text { for some techniques } \\
\text { (such as use of oil for frying, for } \\
\text { example). }\end{array}$ \\
\hline
\end{tabular}

Note: "UN: Unprocessed Food ('in natura'): Directly obtained from nature, without having undergone any change (leaves, fruit, eggs) [16,23]. ${ }^{* *}$ Pre-preparation: Operations preliminary to cooking, or not of food or ingredients (Subdivision: Peeling, chopping, slicing, cutting, carving, decanting, squeezing, straining, centrifuging, sifting; Union: Mixing, beating, hydrating, breading) [43]; Preparation: It involves cooking by heating (Cooking in water: cooking in liquid/steaming, poaching; Cooking without water: broiling, grill baking, stewing, deep frying/frying pan, sautéing, stir-frying; Mixed cooking techniques: Stewing - There is only one verb for 'to stew' in English language which means two diferents actions in Portuguese language: 'guizar' e 'ensopar' [43]).

MP: Minimally Processed ('minimamente processados'): Unprocessed foods subjected to minimal changes (drying, washing, cutting, pasteurizing) $[16,23]$.

Cl: Culinary Ingredients ('ingredientes culinários'): Products extracted from unprocessed foods and used to season or cook foods (oils, fats, sugar and salt) $[16,23]$.

P: Processed ('processsados'): Manufactured with the addition of a cooking ingredient or micro-organisms to unprocessed or minimally processed foods (preserved food, salted, smoked or sweetened, cheeses) [16,23].

UP: Ultra-Processed ('ultraprocessados'): Industrial formulations of several substances derived from foods, generally with little or no whole food (products containing added fat, sugar and/or salt) $[16,23]$.

Thus, cooking skills may be categorized as 'centred on tasks' and 'centred on the person'. The first ones relate to mechanical abilities, such as employing cooking techniques and using certain foods and utensils. The cooking skills centred on the person refer to perceptual and conceptual dimensions, academic knowledge, and planning ability of the person [9].

In some of these review studies, cooking knowledge was evaluated based on the knowledge of terms, techniques and specific tools, which are viewed in this article proposal as 'task-centred components' $[9-11,13,68]$. Thus, it is proposed that task-centred cooking skills may also encompass cooking knowledge.

Yet, the evidence regarding cooking knowledge appears to be unclear. While the diffusion of cooking knowledge occurs widely in various media, such as the Internet and cookbooks, the transmission of cooking knowledge seems to be reduced in school and at home across generations $[1,14,53]$. Also, cooking knowledge may refer to cooking skills centred on the person; consequently, they may have an impact on confidence, attitude, and the individual's cooking behaviour $[6,13,11,68,69]$. 
Similarly, the cooking attitude does not seem to be consensually explored. Some studies regard the interest in cooking as an aspect of cooking attitudes (enjoying cooking, trying out new recipes, etc.), evaluated as positive or negative $[11,13,68]$. Other authors investigate it as a barrier, such as lack of time, or as individual facilitators of cooking, such as the idea that cooking fosters a balanced diet [11-13,69].

Studies on the theme have analysed confidence in cooking as a dimension that might predict the cooking behaviour at home. Confidence is grounded in psychosocial theories, complemented by the evaluation of cooking attitude. These dimensions have been well accepted to assess cooking skills $[1,6,9,12,13,68]$. For instance, in the adult population of the United Kingdom, it was found that confidence in cooking was high (90\%), although this fact is not synonymous with the frequent use of these cooking skills [57].

Despite the identification of previously mentioned limitations, the common elements found in the studies analysed, served as the foundation of the concept of cooking skills for this study $[1,2,4-7,9-12,68]$. Subsequently, a conceptual model was formulated to define cooking skills, as categories related to foods and individuals (Figure 1).

Considering the skills centred on the task (which might lead to using different types of foods and cooking techniques) and the skills centred on the person, cooking skills may be exercised at different levels. The cooking knowledge, already cited as linked to both skills centred on the task and on the person, has been regarded as a basis for learning and, consequently, for increased frequency in food preparation. Therefore, it might contribute to an increase in the attitude and confidence in cooking, suggesting, and an increase in the habit of home cooking, which all reflect cooking behaviour [1,5,8,9,12,68].

However, there is still no evidence that the attitude, self-efficacy and the individual cooking knowledge, demonstrated at different levels, have direct effects on the change in people's cooking behaviour [70]. Yet, they consist of elements of analysis that might indicate a possible predisposition to this change, requiring further investigation [68]. Researchers point out that an individual's displaying a greater frequency in preparation of meals at home might involve greater use of ultra-processed foods, so they might not be characterized as healthy $[7,58]$.

In summary, based on the literature review, it is proposed that cooking skills be conceptualized as: confidence, attitude, and application of individual knowledge to perform cooking tasks that range from planning menus and shopping to food preparation of unprocessed, minimally processed, processed or ultra-processed foods.

\section{CONCLUSION}

Given the relevance and the emergence of the theme of cooking skills on the world scenario and in Brazil, the present review sought to contribute to the scientific debate on its concept. Considering the greater availability of ultra-processed foods, the interest of the public policies in valuing and bringing back cooking to foster healthy eating, as well as the diffusion of cooking shows in the media, this debate seems to contribute to filling a gap found in the scientific literature.

The conceptual model proposed for cooking skills comprised a categorization related to foods and individuals. The food-related category is linked to cooking in the definition of these abilities, starting from the stage of prepreparation and with the use of ingredients/ foods with different degrees of processing. It is worth noting that the classification of prepreparation and preparation stages to establish cooking techniques considered as basic allowed for a pragmatic outlook, echoing classical works in the field of Food and Nutrition in Brazil. 


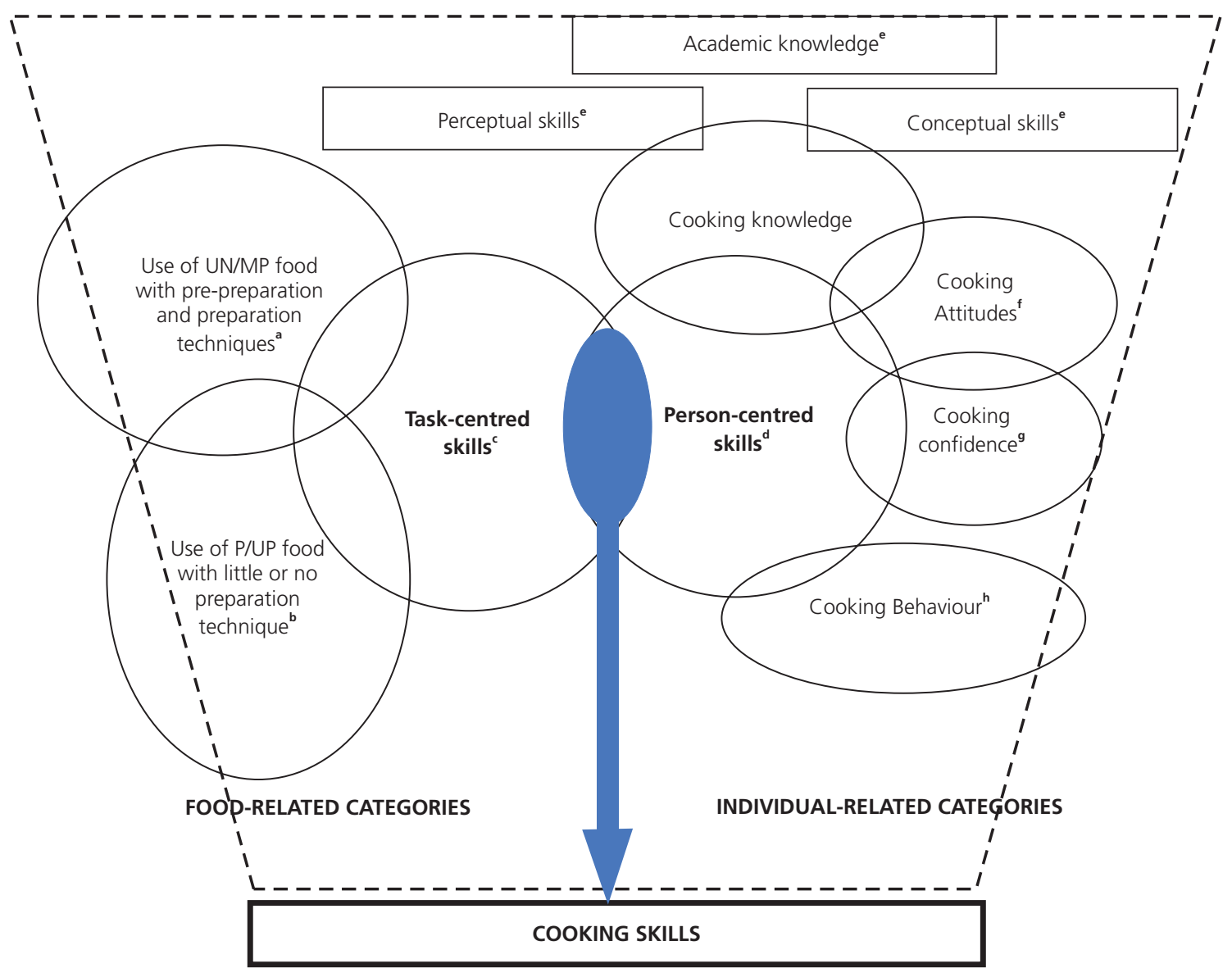

Figure 1. Conceptual model of cooking skills, according to categories related to foods and individuals.

Note: aAlso called 'traditional or domestic'; they are subject to all stages from pre-preparation to final preparation [1]; ' $A l s o$ called 'artificial' or 'technological', having already been subjected to a kind of processing before use in preparation of meals, which may often be only reheated, requiring minimal or zero preparation [1]; 'Use of technical practises and mechanical abilities. They involve the use of cooking techniques

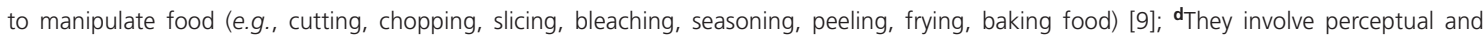
conceptual skills, the academic knowledge, as well as the capacity of planning menus (creative abilities) and organising the preparation of meals (adjusting the time to execute cooking tasks). Attitude, confidence (self-efficacy), behaviour and culinary knowledge are considered individual dimensions to assess cooking skills [1,6,9-13.68]; eperceptual skills are related to the ability to judge flavour, colour and texture of the combinations of ingredients. Conceptual skills are related to the ability to predict results, be creative and demonstrate how to adjust ingredients. The academic knowledge involves knowledge of nutrition, food hygiene, and eating trends. Cooking knowledge is linked to notions of cooking terms and techniques, use of equipment, proper utensils and ingredients, as well as substitution of acceptable ingredients, with a minimum number of mistakes in the final preparation of foods $[11,68]$; fViewed as the interest in preparing food, or as an element of culinary identity, whether positively (ex. enjoying home cooking, trying out new recipes, finding it more viable economically) or negatively (e.g., cooking is exhausting, it takes too long) [68,69]; 9Self-efficacy in the very ability of performing tasks in the kitchen under specific conditions $[1,6,68]$; ${ }^{\text {h } U s i n g ~}$ and reviewing correct activities while practising cooking skills at home [68].

UN/MP: Unprocessed/Minimally Processed; P/UP: Processed/Ultra-Processed.

Regarding the cooking skills category related to individuals, the task-centred categories depend on those centred on the person, such as confidence, attitude and knowledge of food preparation, which might influence the cooking behaviour. These individual elements characterise the way in which and on what level the techniques and ingredients are utilized in food preparation.

It must be pointed out that the proposition of this concept is not exhausted in this article. It is being presented as a point of departure for the 
scientific debate on the theme. The discussion that deserves further development is the relationship between cooking skills and healthy eating habits, pointed as the goal of most of the studies analysed. In addition, there are public health policies focused on cooking in several parts of the world. To do so, it is suggested that unprocessed or minimally processed foods be valued, requiring techniques starting at the stage of pre-preparation, as possibly healthier than using processed and ultra-processed foods.

Finally, the conceptualization of cooking skills hereby proposed may contribute to future investigations on how to evaluate cooking skills, consequently, opening the way for studies analysing cooking interventions to verify its relationship with healthy and sustainable eating.

\section{CONTRIBUTIONS}

MM JOMORI was responsible for the conception and design of the article; collection, analysis and interpretation of data; drafting and writing a critical review of the article; and the approval of its final version. FAG VASCONCELOS contributed to the conception and design of the article; analysis and interpretation of data; writing and critical review of the article; and the approval of the final version of the article. GL BERNARDO and PL UGGIONI contributed to the analysis and interpretation of data; critical review of the article; and the approval of the final version of the article. RPC PROENÇA coordinated the design and drawing of the article, as well as contributing to the analysis and interpretation of data; writing a critical review of the article; and the approval of the final version of the article.

\section{REFERE N CES}

1. Caraher MDP, Dixon P, Lang T, Carr-Hill R. The state of cooking in England: The relationship of cooking skills to food choice. Br Food J. 1999;101(8):590-609. https//:doi.org/10.1108/0 0070709910288289

2. Larson $\mathrm{NI}$, Perry $\mathrm{CL}$, Story $\mathrm{M}$, Neumark-Sztainer D. Food preparation by young adults is associated with better diet quality. J Am Diet Assoc.
2006;106(12):2001-7. https//:doi.org/10.1016/j.jada. 2006.09.008

3. Condrasky MD, Griffin S. Culinary nutrition education model increases cooking at home. J Am Diet Assoc. 2007;107(8 Suppl 1):A11. https://doi. org/10.1016/j.jada.2007.05.042

4. Hartmann C, Dohle S, Siegrist M. Importance of cooking skills for balanced food choices. Appetite. 2013;65(1):125-31. https//:doi.org/10.1016/j.appet. 2013.01.016

5. Reicks M, Trofholz AC, Stang JS, Laska MN. Impact of cooking and home food preparation interventions among adults: Outcomes and implications for future programs. J Nutr Educ Behav. 2014;46(4):259-76. https//:doi.org/10.10 16/j.jneb.2014.02.001

6. Gatley $\mathrm{A}$. The significance of culinary cultures to diet. Br Food J. 2016;118(1):40-59. https//:doi. org/10.1108/BFJ-06-2015-0228

7. Wolfson JA, Bleich $S N$, Smith KC, Frattaroli $S$. What does cooking mean to you? Perceptions of cooking and factors related to cooking behavior. Appetite. 2016;97(1):146-54. https//:doi.org/10.10 16/j.appet.2015.11.030

8. Raber M, Chandra J, Upadhyaya M, Schik V, Strong LL, Durand C, et al. An evidence-based conceptual framework of health cooking. Prev Med Rep. 2016;4:23-8. https//:doi.org/10.1016/j. pmedr.2016.05.004

9. Short F. Domestic cooking skills: What are they? J Home Econ Inst Aust. 2003;10(3):13-22.

10. Begley A, Gallegos D. What's cooking for dietetics? A review of the literature. Nutr Diet. 2010;67(1):26-30. https//:doi.org/10.1111/j.1747 0080.2010.01406.x

11. Byrd-Bredbenner C. Food preparation knowledge and confidence of young adults. J Nutr Recipe Menu Dev. 2005;3(3/4):37-50.

12. Winkler E, Turrell G. Confidence to cook vegetables and the buying habits of Australian households. J Am Diet Assoc. 2010;110(5 Suppl):S52-61. https//: doi.10.1016/j.jada.2010.03.007

13. Condrasky MD, Baruth M, Wilcox S, Carter C, Jordan JF. Cooks training for faith, activity, and nutrition project with AME churches in SC. J Eval Program Plan. 2013;37:43-9. https//:doi.org/10. 1016/j.evalprogplan.2012.11.002

14. Stitt S. An international perspective on food and cooking skills in education. $\mathrm{Br}$ Food J. 1996;98(10):27-34. https//:doi.org/10.1108/00070 709610153795

15. Caraher M, Lang T. Can't cook, won't cook: A review of cooking skills and their relevance to 
health promotion. Int J Health Promot Educ. 1999;37(3):89-100.

16. Monteiro CA, Cannon G, Levy RB, Moubarac JC, Jaime $P$, Martins $A P$, et al. NOVA.The star shines bright. [Food classification public health]. World Nutr. 2016 [cited 2016 Jul 3];7(1-3):28-38. Available from: http://wphna.org/wp-content/ uploads/2016/01MN-2016-7-1-3-28-38-MonteiroCannon-Levy-et-al-NOVA.pdf

17. Health Promotion Agency for Northern Ireland. Cook it! An evaluation of a community nutrition education programme in Northern Ireland. Belfast: Health Promotion Agency; 2009 [cited 2014 Sept 3]. Available from: http://www.thehealthwell.info/ node/61564

18. Chenhall C. Improving cooking and food preparation skills: A synthesis of the evidence to inform program. Ottawa: Health Canada; 2010 [cited 2014 Sept 3]. Available from: http://www. healthcanada.gc.ca

19. United States Department of Agriculture. United States Department of Health and Human Services. Dietary Guidelines for Americans, 2010. 7th ed. Washington (DC): U.S. Government Printing Office; 2010 [cited 2015 Jan 31]. Available from: https://health.gov/dietaryguidelines/dga2010/ dietaryguidelines2010.pdf

20. National Institute of Food and Agriculture. Food Policy: Current EFNEP Programming Reflects the 2010 U.S. Dietary Guidelines. Topeka (KS); 2011 [cited 2015 Jan 31]. Available from: https://nifa. usda.gov/sites/default/files/resources/Report\%20 \%20EFNEP\%20Alignment\%20with\%202010\% 20Dietary\%20Guidelines.pdf

21. Ministério do Desenvolvimento Social e Combate à Fome (Brasil). Marco de referência de educação alimentar e nutricional para as políticas públicas. Brasília: MDS; 2012 [acesso 2014 jan 31]. Disponível em: http://www.mds.gov.br/webarquivos/ publicacao/seguranca_alimentar/marco_EAN.pdf

22. Community Food and Health Scotland. The impact of cooking courses on families: A summary of a research study comparing three different approaches. Edinburgh: Publishing Manager at NHS Health Scotland; 2013 [cited 2014 Sept 20]. Available from: http://www.communityfoodandhealth.org. uk/wp-content/uploads/2013/04/CFHS-impactcooking-courses-families.pdf

23. Ministry of Health (Brazil). Secretariat of Health Care Department. Dietary Guidelines for the Brazilian Population. 2nd ed. Brasília: Ministry of Health; 2014 [cited 2015 Jul 11]. Available from: http://189.28.128.100/dab/docs/portaldab/ publicacoes/guia_alimentar_populacao_ingles.pdf
24. Diez-Garcia RW, Castro IRRD. A culinária como de estudo e de intervenção no campo da alimentação e nutrição. Ciênc Saúde Coletiva. 2011;16(1):91-8. https//:doi.org/10.1590/S1413-812320110001000 13

25. Flandrin JL. Da dietética à gastronomia ou a libertação da gula. In: Flandrin JL, Montanari M. História da alimentação. 4a ed. São Paulo: Estação Liberdade; 1998.

26. Freyre G. Manifesto regionalista de 1926. Recife: Instituto Joaquim Nabuco de Pesquisas Sociais; 1967.

27. Vasconcelos FAG. Rich man's food, poor man's food in "The mansions and the shanties": A narrative review of the book written by Gilberto Freyre. Rev Nutr. 2016;29(2):269-85. http//:doi. org/10.1590/1678-98652016000200010

28. Freyre G. Sobrados e mucambos: decadência do patriarcado rural e desenvolvimento do urbano. 2a ed. Rio de Janeiro: J. Olympio; 1951.

29. Freyre G. Nordeste: aspecto da influência da cana sobre a vida e a paisagem do nordeste do Brasil. Rio de Janeiro: J. Olympio; 1937.

30. Freyre G. Açúcar. Rio de Janeiro: IAA; 1969.

31. Freyre G. Casa-grande e senzala: formação da família brasileira sob o regime da economia patriarcal. 50a ed. São Paulo: Global; 2005.

32. Vasconcelos FAG. A ciência da nutrição em trânsito: da nutrição e dietética à nutrigenômica. Rev Nutr. 2010;23(6):935-45. https//:doi.org/10.1590/ S1415-52732010000600001

33. Vasconcelos FAG. Tendências históricas dos estudos dietéticos no Brasil. Hist Ciênc Saúde-Manguinhos. 2007;14(1):197-219.

34. Vasconcelos FAG. Os Arquivos Brasileiros de Nutrição: uma revisão sobre produção científica em nutrição no Brasil (1944 a 1968). Cad Saúde Pública. 1999; 15(2):303-16. http://dx.doi.org/10.1590/s0 102-311X1999000200015

35. Lima ES. Gênese e constituição da educação alimentar: a instauração da norma. Hist Ciênc Saude-Manguinhos. 1998;5(1):57-84.

36. Querino MR. A arte culinária na Bahia. Salvador: Livraria Progresso Editora; 1957.

37. Costa DN. Bases da alimentação racional. São Paulo: Companhia Editora Nacional; 1938.

38. Siqueira R. Notas para um "planning" alimentar brasileiro. Rev Serv Público. 2013;64(3):393-412. https://doi.org/10.21874/rsp.v64i3

39. Veloso CS. A gastrotécnica na alimentação brasileira: breve ensaio de história social, antropologia 
e sociologia. Rio de Janeiro: Jornal do Commercio; 1941.

40. Júnior JP. Alimentação: problema nacional. Rio de Janeiro: Off. Graph. Mauá; 1941.

41. Botelho T. Pequenos fundamentos da boa alimentação. Rio de Janeiro: Serviço de Propaganda e Educação Sanitária; 1938.

42. Ministério da Educação e Cultura (Brasil). Os cursos de nutrição no Brasil: evolução, corpo docente e currículo. Brasília. 1983 [acesso 2016 jul 11]. Série de Cadernos de Ciências da Saúde, 6. Disponível em: http://www.dominiopublico.gov.br/ download/texto/me002281.pdf

43. Ornellas LH. Técnica dietética: seleção e preparo dos alimentos. 8a ed. São Paulo: Atheneu; 2006.

44. Lévi-Strauss C. O cru e o cozido. 2a ed. São Paulo: Cosac Naify; 2010. (Mitológicas; v.1).

45. Freitas MCS, Minayo MCS, Fontes GAV. Sobre o campo da alimentação e nutrição na perspectiva das teorias compreensivas. Ciênc Saúde Coletiva. 2011;16(1):31-8. http//:doi.org/10.1590/\$1413-812 32011000100008

46. Câmara dos Deputados (Brasil). Lei $n^{\circ} 4.024$, de 20 de dezembro de 1961. Lei de Diretrizes e Bases da Educação Nacional. Câmara dos Deputados. 196120 dez. [acesso 29 abr 2015]. Disponível em: http://www2.camara.leg.br/legin/ fed/lei/1960-1969/lei-4024-20-dezembro-1961353722-normaatualizada-pl.pdf

47. Edwards JSA. Culinary Pleasures: Cookbooks and the transformation of British Food. J Foodserv. 2006;17(1):60-1. http//:doi.org/10.1111/j.1745-45 06.2006.00016.x

48. Barham PA. A ciência da culinária. São Paulo: Rocca; 2002.

49. This H. Um cientista na cozinha. 4a ed. São Paulo: Ática; 2007.

50. Assunção VK. Da TV para a mesa: as relações entre alimentação e recepção de programas de culinária. In: Guivant JS, Spaargare G, Rial C, organizadores. Novas práticas alimentares no mercado global. Florianópolis: Editora UFSC; 2010.

51. Caraher M, Seeley A. Cooking in schools: Lessons from the UK. J HEIA. 2010;17(1):2-9.

52. Proença RPC. Alimentação e globalização: algumas reflexões. Ciênc Cult. 2010; [acesso 2015 jul 11];62(4):43-7. Disponível em: http://ciencia ecultura.bvs.br/scielo.php?script=sci_arttext\&pid= S0009-67252010000400014\&lng=en\&nrm=iso

53. Worsley A, Wang W, Ismail S, Ridley S. Consumers' interest in learning about cooking: The influence of age, gender and education. Int J Consum Stud. 2014;38(3):258-64. http//:doi.org/10.1111/ ijcs. 12089

54. Mintz SW. Tasting food, tasting freedom. Excursion into eating, culture, and the past. Boston: Beacon Press; 1996.

55. Diez-Garcia RW. Notas sobre a origem da culinária: uma abordagem evolutiva. Rev Nutr.1995;8(2):231-44.

56. Condrasky MD, Hegler M. How culinary nutrition can save the health of a nation. J Ext. 2010;48(2):1-6.

57. Adams J, Goffe L, Adamson AJ, Halligan J, O'Brien N, Purves R, et al. Prevalence and sociodemographic correlates of cooking skills in UK adults: Cross-sectional analysis of data from the UK National Diet and Nutrition Survey. Int J Behav Nutr Phys Act. 2015;12(1):1-13. http//:doi. org/10.1186/s12966-015-0261-x

58. Lavelle F, McGowan L, Spence M, Caraher M, Raats MM, Hollywood L, et al. Barriers and facilitators to cooking from 'scratch' using basic or raw ingredients: A qualitative interview study. Appetite. 2016;107(1):383-91. http//:doi.org/10. 1016/j.appet.2016.08.115

59. Castro IRR, Souza TSN, Maldonado LA, Caniné ES, Rotenberg S, Gugelmin SA. A culinária na promoção da alimentação saudável: delineamento e experimentação de método educativo dirigido a adolescentes e a profissionais das redes de saúde e de educação. Rev Nutr. 2007;20(6):571-88. http//:doi.org/10.1590/S1415-52732007000600 001

60. Alencar B, Toral N, Recine E, Rizzolo A. Factors related to food involvement in the adult population Rev Nutr. 2016;29(3):337-45. http//:doi.org/10.15 90/1678-98652016000300004

61. Massané T. Cuisine (Historique): Stratégie alimentaire humaine. In: Poulain J-P, organizer. Dictionnaire des cultures alimentaires. Paris: Press Universitaires de France; 2012.

62. Brillat-Savarin A. A fisiologia do gosto. São Paulo: Companhia das Letras; 1995.

63. Fischler C. L'Homnivore: Le goût, la cuisine et le corps. Paris: Éditions Odile Jacob; 2001.

64. Symons M. Cutting up cultures. J Hist Sociol. 2002;15(4):431-50.

65. Poulain JP, Proença RPC. Reflexões metodológicas para o estudo das práticas alimentares. Rev Nutr. 2004;16(4):365-86. http//:doi.org/10.1590/S141 5-52732003000400001

66. Poulain J-P. Les jeunes seniors et leur alimentation. Paris: Cahiers de l'OCHA; 1998. n.9. 
67. Proença RPC. Inovação tecnológica na produção de alimentação coletiva. Florianópolis: Insular; 2000.

68. Michaud P. Development and evaluation of instruments to measure the effectiveness of a culinary and Nutrition education program [thesis]. Clemson: Clemson University; 2007.

69. Jones S, Walter J, Soliah L, Phifer JT. Perceived motivators to home food preparation: Focus group findings. J Acad Nutr Diet. 2014;114(10):1552-6. http//:doi.org/10.1016/j.jand.2014.05.003
70. Murray DW, Mahadevan M, Gatto K, O'Connor K, Fissinger A, Bailey D, et al. Culinary efficacy: An exploratory study of skills, confidence, and healthy cooking competencies among university students. Perspect Public Health. 2016;136(3):143-51. http//:doi.org/10.1177/1757913915600195

Received: November 10, 2016

Final version: June 5, 2017

Approved: July 25, 2017 